\title{
Territorial Mobility and the Mamprusi Kingship
}

\author{
Dr Susan Drucker-Brown
}

\section{(2) OpenEdition}

\section{Journals}

Édition électronique

URL : http://journals.openedition.org/span/1690

DOI : $10.4000 /$ span. 1690

ISSN : 2268-1558

\section{Éditeur}

École pratique des hautes études. Sciences humaines

\section{Édition imprimée}

Date de publication : 1 janvier 2014

Pagination : 101-116

ISBN : 9782909036434

ISSN : 0294-7080

Référence électronique

Dr Susan Drucker-Brown, "Territorial Mobility and the Mamprusi Kingship », Systèmes de pensée en Afrique noire [En ligne], 19 | 2014, mis en ligne le 05 février 2020, consulté le 11 février 2020. URL : http://journals.openedition.org/span/1690; DOI : 10.4000/span.1690 


\section{Territorial Mobility and the Mamprusi Kingship}

\section{Dr Susan Drucker-Brown}

Department of Social Anthropology

University of Cambridge

In December of 1965 I had recently returned from two years of fieldwork in northern Ghana. My supervisor, Prof. Meyer Fortes, invited me to accompany him and his wife Doris to a conference in the village of Sonchamp, outside Paris ${ }^{1}$. There we were welcomed with wonderful hospitality by Germaine Dieterlen at her home. The three-day Sonchamp meeting was my first introduction to French anthropologists and it was a truly momentous occasion. As I remember it, the grown-ups, (ie. the more senior participants), stayed at Germaine's house, while we, (" children ") stayed in the local hotel. However, once reunited at Germaine's house for daily meetings, and sumptuous lunches, the atmosphere was so relaxed and friendly that everyone participated in the discussions. The exchanges were exciting, and stimulated all of us. We had so much in common that all conversation extended our diverse understandings. Michel Cartry and I had much in common and meeting him at Sonchamp began our friendship.

Fortes, in his summing up of the meetings ${ }^{2}$, emphasised the common element in the societies we were dealing with. He pointed out that we had spoken very little about economics and noted that the Voltaic area of West Africa, where we were all working, is large but homogeneous in terms of the hoe agriculture on which the economy is based. Similarly homogeneous, was the widespread distribution of

\footnotetext{
${ }^{1}$ Sonchamp, Yvelines (6.9 décembre 1965).

${ }^{2}$ Fortes. 1967.
}

Comparer les systèmes de pensée

Systèmes de pensée en Afrique noire, 19, 2014, pp. 101-116 
patrilineal kinship groups and the polar opposition of patrilineal descent groupings with a cult of the earth. A further distinction, also widespread, was the opposition between polities associated with kingship and those in which patrilineal kinship provided the wider framework for political organization.

My fieldwork had been focussed on the Mamprusi region, in northern Ghana. The Mamprusi king, Nayiiri, is regarded as the most senior among a cluster of kings descended from a common founder. Descendants of $\mathrm{Na}$ Gbewa; the founding monarch, are members of royal lineages among the Mossi, Dagomba, Nanumba, Wala, Grumatche, as well as in settlements which are not traditionally part of centralized polities; the Tallenis Namoos for example.

The monarchical polities are organized through the allocation of Naam; a transcendental element which Gbewa brought with him and which is now distributed among the different kingdoms, embodied in royal chiefs and kings through a combination of patrilineal descent and rituals of installation. I have not space here for a comparison of the related forms of kingship but hope that the model I will present of the Mamprusi case may, in future, aid such an analysis.

Crucial to my argument here is Fortes' observation that the Mamprusi polity, like the political organization based on patrilineal descent groups, operates in a territory where slash and burn agriculture is the basic form of agricultural land use. This makes some degree of spatial mobility in settlement patterns inevitable. Fortes ${ }^{3}$ analyzes the ways in which a Tallensi lineage may divide, as segments abandon an area which has become infertile, to build new houses and open new farms in land which has been fallowed. A senior household head will return from a new farm to the older settlement as successor to headship of the larger lineage segment.

Mamprusi settlements move in a different fashion. Unlike the Tallensi whose farms are scattered around their domestic living space, the Mamprusi live in nucleated sett- 
lements and farm outside the residential area of a village. Although individual household heads make farms in the bush and may reside for periods on those farms, such settlements are regarded as temporary and no permanent houses are build. Settlements seem to move with the creation of new chiefships and older villages sites are abandoned. The names and obligations associated with abandoned villages are commemorate in the new settlements and those chiefs buried in abandoned sites will receive sacrifices from chiefs in the new sites.

The contrast drawn by Fortes and Evans-Pritchard ${ }^{4}$ between centralized and acephalous societies has been much used and much criticized. Usually targeted is the characterization of the acephalous polity based on segmentary lineage organization. No-one who has worked in the Voltaic region where kingdoms and segmentary lineage based socieites interact, can fail to see the importance of the contrast. In this presentation however, I want to focus on a loose form of centralization characteristic of the Mamprusi kingdom and on the significance of the immobilized king within that structure. I prefer to see this as a " centralizing " rather than a centralized polity.

The ways in which the element Mamprusi call "naam " moves through space and time, seems to me to be crucial in the centralizing process. I will argue here that the flow of naam, discussed in more detail below, provide the mechanism for that centralization. The domination by the centre of the small, dispersed settlements which constitute the kingdom depends on willingly provided information which is accumulated at the king's court, later to be used and disseminated along the pathways established with the flow of naam. All paths lead to the king and his court.

\section{King House, the Hut and the Mobile Polity}

Memprusi people say of their king, that he owns the whole world and everything in it. In a sense this is tantamount to rejecting the notion of territorial boundaries for it asserts that ultimately there are no other owners. The

${ }^{4}$ Fortes \& Evans

Pritchard, 1940. 
customary greeting of the Nayiiri and of village chiefs by Mamprusi people constitutes recognition of this unique aspect of the kingship, Mamprusi value the etiquette of court behaviour; commoner and royals both take pride in that knowledge. Honouring a chief means that village chiefs will be greeted at least once a week by all household heads and their wives will greet the chief's wives. Court elders will greet the chief daily. Greeting the chief does in fact, transform people from other ethnic groups and Mamprusi say, they turn into Mamprusi (Labigi Mampruga) when people participate in courts following the proper physical and linguistic patterns.

Mamprusi use their chiefs in various ways. Marriages are established through the transmission of kola from groom to the bride's kin. The marriage kola will be passed through the chief, who supervises the kola payment or its return. Requests for land to build, or to farm will be made to the chief, who with his court will supervise the allocation of specific territory. Sacrifices will be provided by the chief to local shrines where these are demanded. Chiefs' courts will set the dates for important funerals. Above all, disputes arising in the village or in village households, which cannot be resolved in the domewstic unit, will be taken to the chief for arbitration and if he cannot settle the dispute he will send it to the king.

Information about deaths of important persons and the installation of lesser chiefs performed by a village chief, will also be sent to the king. Village chiefs greet the king at annual festivals and attend other ceremonies in the capital. They may accompany or be called to bear witness in the judgement of disputes where they have specific relevant knowledge. The Nayiiri will send representatives to attend funerals of royal chiefs and important commoners. Some portion of the animals sacrificed during the funerals will be sent to the capital from the funeral house.

The etiquette of honouring the king is more elaborate than that used in any chief s court. No Mamprusi should mention the king's name, except as an oath. The 
new king chooses his kingship name from the vocabulary of everyday speech; such words : snake, needle, door, become unmentionable and are then replaced in everyday speech by euphemisms; sharp pointed thing = needle, rope $=$ snake. The king is not viewed directly by most of his subjects who cast their eyes down in his presence. Special physical greetings are used for him. Men sit on the ground and clap gently while intoning " naa ». Women crouch, bending forward with faces averted and click their fingers in greeting. On ceremonial occasions the king's words, and those spoken to him are relayed back and forth, like objects, by special members of his court.

In the past Nayiiri was forbidden to cross the two streams which ran through the capital village. He is forbidden to move rapidly nor may any part of his body touch the bare earth lest his people suffer from a skin rash. The skins on which the Mamprusi king sits are spread on special platforms. They are skins of animals which he has sacrificed to his ancestors, or those of animals like lion and leopard, which may be themselves incarnations of kings. Skins are synonymous with office, both chiefly office and kingship. The king however, unlike village chiefs, cannot move unaccompanied by the skins. These are carried by a specific elder or servant. He is believed to move invisibly at night, and may take any form he wishes. However, the prohibitions on his daily movement, make him dependent on his court and on his wives for his survival.

In addition to attendance at his court by other chiefs and their representatives, the king receives personal greetings and gifts in kind from visiting strangers and in particular from persons seeking office. These are mainly members of the royal lineages, but may also include commoners who have adopted Mamprusi custom with respect to chiefly office, namely that it should be the prize in a competition rather than achieved automatically through genealogical position.

Contestants involved in competition for office regularly greet the king and his elders. Their greeting are accom- 
panied by gifts, of varying value but always involves verbal greeting. Mamprusi love conversation. A proverb says "Azama gari ligri " (" conversation is greater than money. ") With the greetings the king receives a wide range of information : descriptions of conditions in all parts of the kingdom, weather, crops, rivalries in competitions for chiefship, the movement of farms, etc. The immobility of the king ensures that he and members of his court will recieve the constant flow of information which accompanies greeting. It is interesting to note that princes, and chiefs are particularly skilled at eliciting information without themselves providing information ( $\mathrm{Na}$ Sheriga's reaction to my recording machine).

Mamprusi believe that the king is omniscient. Until the introduction of mass media, he did indeed have greater access to information than any other citizen of his kingdom for greeting a chief is the obligation of all Mamprusi, and greeting the king is an obligation of chiefs. Royals who become chiefs also wish to become king. The incentives for greeting the king and his court are built into the competitions for office, and these in turn produce a movement from the periphery to the capital village.

\section{Territory : Movement in space}

The Mamprusi king's title, Nayiiri (King House), is an assertion that he is a place of origin. His title differs from that of all other chiefs and neighbouring kings in that it makes no reference to any specific territory. Nayiiri (the title "King House ") refers only to the residence of naam. The titles of neighbouring chiefs and kings refer to specific territories as in Mogonaba, King of the Bush (Mooni) Yanaba, King of the forest (Yongo).

Mamprusi call themselves " Dagbamba ", a designation that places them in a central position with respect to the inhabitants of the bush (to the north) or the forest (to the south).

Mamprusi say, "there cannot be two chiefs in one village ». This mutual repulsion is seen as an aspect of the flow of naam which ultimately draws all chiefs to King House or 
leads to the avoidance of a senior by his juniors which is a feature of Mamprusi behaviour among kin. ( $\mathrm{Na}$ Sheriga told me proudly of a visit he made to Burkina Fasso. He had brought a gift for his grandson, the Mogonaba, but the Mogonaba did not meet him. "I wonder why? " he said to me, proudly.)

Spatial mobility can also be a weapon of protection against chiefly abuse. One chiefly title is said, in a story often told, to commemorate an abusive chief who was abandoned by his village, and later, much humiliated, rejoined them.

Spatial movement of the capital village itself, is commemorated in sacrifices made or provided by the Nayiiri to priests who perform the sacrifices. Each new king must send an animal for sacrifice to locations of ancestral Nayiiri's grave sites. First among these is Pusiga where the founding king, $\mathrm{Na}$ Gbewa, was swallowed up by the earth on hearing of the death of his favourite son. The Kusase earth-priest of Pusiga, performs the sacrifice on behalf of the Nayiiri. The Mamprusi chief of Gambaga is an earth priest who sacrifices at a shrine in Tamalerigu, some 6 miles from Gambaga, in uninhabited bush. This is where the capitol moved from Pusiga. The capital then moved from Tamalerigu to Gambaga, where the Gambaga chief is again in charge of the graves of former kings. Finally, the kingdom moved from Gambaga to its present site in Nalerigu. Pusiga is some $60-70$ miles northeast of Gambaga; it lies beyond the escarpment which separates the flat but fertile lands of the Kusase and Tallensi, from the more wooded hills on the south side of the escarpment where Gambaga, Tamalerigu and Nalerigu are all located. I have already suggested that this movement of the capital is consistent with the pattern of shifting cultivation. However it is also consistent with a concern, which we have seen, for secluding the king.

\section{The King's Body and the flow of naam}


As we have already said, the king's body and those of royal chiefs contain the element Mamprusi call Naam. The final " $\mathrm{m}$ " indicates that a noun belongs to a class of words referring to elements such as fire (bugum) or water (kom) which are infinitely divisible without changing their essence. The word naam may be translated as " power " as Michel Izard (1985) does but I have used the translation " office " in the Weberian sense of a vocation or calling. Office, as Fortes puts it, exists outside of the holder and rituals of installation are a means of uniting the person with the office. In the Mamprusi case, the individual holder, (naam-owner) as Mamprusi would say, must have inherited the capacity to receive naam before it can be embodied in him through rituals of installation. Once embodied naam cannot be revoked or removed. There is no ritual means of deposing a Mamprusi chief or king as happens in Ashanti.

All office endures for the life of its holder. This is true of commoner as well as royal office-holders. However in the case of a royal chief s death, he is returned in effigy to the living king and the ancestral kings, who will re-allocate naam to new holders [...]. This cyclical movement of naam concentrated in its most powerful form in the body of king, and then allocated in portions to princes who carry it from the king to villages throughout the kingdom, returning at death to the king and his ancestor shrine in the palace, is the framework for centralization the Mamprusi polity.

Elsewhere I have likened the flow of naam, to the physical process of convection, in which heat moves from a central point through a liquid medium in circulating " cells". These cells may form smaller cells as heat moves through the medium. The difference between the convection model of centralization, and the more common pyramidal model of a centralized hierarchy lies not only in the fact that the convection model emphasizes spatial movement, but also in that it does not assume relations of inequality within cons the model nor stratification of any kind. Convection cells are linked only to distinct sources of heat and ultimately to the central source, not to one another. 
This is appropriate to the Mamprusi case. Mamprusi envisage and speak of the King as " father " to all Na's children referring to members of the royal clan. However, these individuals are internally divided by lineage and generation. Mamprusi say that it is because of naam, that they are his children; not because of kinship (doa'am).

There is practically no emphasis at all on the relationship between siblings which would accompany a patri-filial kinship connection. Seniority among particular chiefs may be mentioned occasionally but it is universally accepted that royal siblings are likely to be rivals and that normally they will avoid one another. Other chiefs of commoner lineages are also difficult to rank since they, like royal chiefs are seen to perform specific tasks on behalf of the king. In the presence of the king all status distinctions among visitors to court are reduced to dyadic relations between them and the king. Commoners are divided among the distinct title classes of king's elders, while all royals, regardless of their geneaological positions, become king's children called " those who cut grass for the kings' horses ", and are seated, most distant from Nayiiiri, together with strangers.

In the convection analogy then, the king's body, and the ancestral relics in his house, are the source of naam, which is like heat. The princes who become chiefs, embody naam which they carry to and from outlying settlements and may themselves reallocate portions of naam to others.

"Nayiiri " is the king's title but it is also the name given to the houses throughout the kingdom in which royal chiefs reside and hold court. The King's house, or palace, is distinct from his title. The Nayiiri's house is referred to as "nayiini " or "nabsaani "; the inside of na, or the presence of na. The identification of chiefs houses with the living king emphasizes his presence beyond the confines of his house and confirms a view of the kingdom as a set of regions within which settlements are linked to the king's house by the coming and going of the naam embodied in royal chiefs.

Given the importance of the bodies which are vehicles 
for naam it is not surprising that installation of both king and princes involves clothing, eating and drinking all of which transform the body (Drucker-Brown, 1989). The King's body is most totally transformed and this transformation occurs immediately after the name of the chosen prince is announced. The announcement is made when the capital is more crowded than on any other occasion. Princes and chiefs involved in the competition will have come from all parts of the central province of the kingdom. The competitors bring their supporters and numbers are significant. The announcement is made by a senior elder with the phrase : "If you do not like the choice, find an empty (uninhabited) space and play. Then bring me my husband. " Thus, the central source of naam is presented as prize which may be fought for though this has not happened in living memory.

In the secret ceremony of investiture, at nightfall after the naming ritual, the palace is encircled by armed warriors. The chosen prince is brought by the elders with whom he has lodged, and under the supervision of a particular priest-chief (Sagadugunaba) he is undressed, shaved, washed and fed like a child. He is then placed on a stone which itself embodies an ancestral king. This occurs seven times throughout the night while a praise-singer chants the names of the departed kings and princes, together with associated references to myth and history. The special stew fed to the king, is prepared from those very animals which all Mamprusi prohibit. In a later phase of the king's installation he eats and drinks at commoner-ancestor shrines, surrounded by a crowd including all sectors of his people who symbolically support him as he consumes the millet cakes and water shared with the commoner ancestors.

In the final phase of his installation the king feeds his people, sharing the stew of forbidden and medicated meats with the princes who hope to inherit the kingship in future.

Succession to kingship provides us with an example of naam circulating in time, rather than in space.

When the Nayiiri dies, his court will choose a succes- 
sor. An election procedure was introduced by the British, modified by the Mamprusi and now adhered to seemingly without question. Seven elders of the court, all with some priestly functions, select the new king from among those princes who are village chiefs. If asked who can become king the elders will respond : «A nabia, who is not lacking an eye, a nostril, a finger, or a toe ". These negative rules emphasize that the king's body must be intact, however there are other more complex negative rules which are harder to elicit. A king may not be succeeded by his own son, nor should a prince succeede who has not bee a village chief. The prince chosen should belong to that lineage of the royal clan which has longest been out of office. The three generation deep lineages which compete for kingship are called "gates " and the elders will try to retain as many gates as possible in the competition, thus ensuring the widest possible pool of candidates. The reigning king, by contrast, will try to see that as many of his own sons as possible hold chiefship to ensure the perpetuity of his own name in his gate.

The spatial metaphor of a Royal gates bring us back again to the king's house. The Nayiiri's, title expresses more than an identification with his residence. We have seen that it identifies him with royal chiefs throughout the kingdom. But his house is also his tomb. He will be buried in a small store-room next to his sleeping quarters. His death initiates the destruction of the palace.

As soon as his death is announced grandchildren will invade and loot the palace. His wives will attempt to save what they can from this invasion sending their possessions out of the palace as the grandchildren enter. The executioner-elders will make a large hole in the wall where a guinea fowl-house has been specially built at one side of the entrance gate. A member of the executioner's lineage will live in the fowl-house and guard the gate, throughout the interregnum. After the interregnum, when princes come to perform the final funeral, this hole (mockingly called a " zongo ", or " hall "), will be used as the entry for princes 
The princes will not enter the palace through the gate but will be dragged through this new entrance.

Once the investiture of the new king is completed on that very night, the palace will be dismantled. The wooden beams used for thresholds, windows, doors and roofs will be removed, the floor will be dug up to remove medicines, the deceased king's destiny shrine will be flattened, and the mud walls left to collapse in the rains.

The new king must build a new house. Mamprusi say he will rebuild his father's house, and ideally he might construct the new house on the very site of his father's grave. More likely however, he takes earth from that grave site and incorporates it into the new building. Until recently the house of the living king was surrounded by an uninhabited area containing the graves of his most recent predecessors.

The location of grave sites in the capital constitutes a map of recent successions. But royals do not express interest except in their own immediate kin hence it is only the senior commoner elders to whom this map is intelligible. Though some of the more recent grave sites are marked by remnants of the original constructions and some older sites are marked by large trees, other grave sites must have disappeared completely. I suspect that sites may be identified as royal graves but the connections between living royals and those kings buried in ancient or unmarked sites, will have led to some transformation in their use as shrines. Like the shrines of ancestral kings in abandoned capital sites which are served by earth-priests rather than descendants of those king this may be true within the capital itself and some of the Nayiiri's elders, rather than royal lineage members, may perform sacrifices at these sites on their behalf.

If the construction of the a new palace is regarded as rebuilding a father's house, and thus recalls the death of a new king's father, the manner in which the palace is constructed suggests the new king's own death.

In ordinary Mamprusi houses the circular walls of the rooms are built by raising layer upon layer of mud as though building up the sides of an enormous pot. The rooms are 
then connected by a circular wall. The palace is constructed differently. A series of grass huts are woven, one for each room of the new palace. These are called Suga, and they form a grass model of the palace. Once the king takes up residence in these huts, with his wives and children, the huts are gradually replaced by the normal mud-walled rooms. However, at least one suga should be retained for an entire year and any child born during that year will be called " Suguri ».

This distinctive name for children born during the first year of a king's reign provides a means of dating the reign and if the child survives into adulthood, also of calculating its length. A similar practice is followed in the construction of royal chiefs' houses except that only one suga is constructed rather than an entire house.

Construction of the king's suga prefigures his death because the announcement of a king's death is made with the phrase, "Bugum-ma voli suga" ("Fire has swallowed the hut "). These conventional words are pure metaphor. At the time of a king's death there is no suga and there is no fire in the capital. The reference is to the initial construction. Yet the phrase conjures up a vision of disaster which draws power from several different sources. The looting grandchildren who consume property might be likened to fire. Throughout Africa new kings often introduce new fire. A flint which is used to make fire is one of the contents of the effigy basked returned to the palace when a royal chief dies. The construction of a new house for the new king does, of course, imply a new fire.

On the other hand, in Mamprusi houses fire is often a source of domestic tragedy. Thatch and wood are often dangerously close to cooking fires. To live in a grass house, or even to have one grass room in the presence of normal domestic activities is to be in an unsafe environment. The suga must make the king particularly aware of his dependence on those who serve him. The announcement of a king's death with an image of burning grass huts can only emphasize the vulnerability of the new king. 
The suga has other meanings. In normal speech suga is part of normal farming practice. Suga is a grass hut built near newly cleared "bush farms ", to provides shelter and a place to sleep when the farm is distant from the farmers home. The imagery of farming used in chiefly installations resonates with the image of the king's suga. The King, when installing a new chief, will ask him to care for his farm, or make some reference to the tasks performed by young boys on their fathers farms. The suga-palace seems to identify the entire Mamprusi polity as the king's bush farm.

\section{Conclusion}

I have presented here a series of metaphors drawn from Mamprusi rituals and customary procedures surrounding the kingship. I have focussed particularly on metaphors, images and evidence of spatial movement in the polity as a whole. The analogy of convection for the accumulation and reallocation of office in the centre of the polity, presided over by king and court, suggests an alternative to the more rigid pyramidal model of hierarchy and seems appropriate for a fluid political structure which must have incorporated people whose location in space was largely determined by their economy of slash and burn agriculture.

I hope also to have shown the extent to which the king is regarded both as omnipotent and vulnerable. The dependence of the king on his court both shields him and provides him with means to deal with his people at a distance. In Hocart's view, "the invention of a man who does no work with his hands (and such work is explicitly forbidden the Nayiiri) but acts on his environment at a distance, was nothing less than the invention of government ". This seclusion of the king is also a spatial fact. People must be drawn to him he cannot travel. It is remarkable, given his seclusion, that they continue to be drawn, and if important chiefs do not come to greet him that absence is interpreted as avoidance, which in turn is a proof of his strength. 


\section{Références bibliographiques}

Drucker-Brown, S.

1989 "Mamprusi installation ritual and centralisation; a convection model", MAN, vol. 24, n 3, p. 485-501.

1999 "The Mamprusi King's funeral play; ritual rebellion revisited in Northern Ghana ", JRAI [incorporating MAN], vol. 5, $n^{\circ} 2$.

Fortes, M. \& Evans-Pritchard, E. E. (eds)

1940 African Political Systems, Oxford, Oxford University Press.

Fortes, M.

1945 The Dynamics of Clanship Among The Tallensi, Londres, Oxford University Press.

1967 "Colloque sur les cultures voltä̈ques ", (Sonchamp 6-8 décembre 1965), Paris, CNRS, "Recherches Voltaïques, 8 ".

Hocart, A. M.

1927 Kingship, Oxford, Oxford University Press.

Izard, M.

1985 Gens du pouvoir, gens de la terre. Les institutions politiques de l'ancien royaume de Yatenga (Bassin de la Volta blanche), Cambridge, Cambridge University Press. 